\title{
Population consequences of biomass loss due to commercial collection of the wild seaweed Postelsia palmaeformis
}

\author{
Sarah Ann Thompson ${ }^{1,2}$, Heather Knoll ${ }^{1}$, Carol A. Blanchette ${ }^{3}$, Karina J. Nielsen ${ }^{1, *}$ \\ ${ }^{1}$ Sonoma State University, Department of Biology, 1801 E Cotati Ave., Rohnert Park, California 94928, USA \\ ${ }^{2}$ Farallon Institute for Advanced Ecosystem Research, PO Box 750756, Petaluma, California 94975, USA \\ ${ }^{3}$ Marine Science Institute, University of California, Santa Barbara, California 93106, USA
}

\begin{abstract}
Commercial take of Postelsia palmaeformis (hereafter Postelsia), an annual kelp found only on wave-exposed, rocky shores of the Northeast Pacific, is increasing rapidly in California where regulation of the edible seaweed 'fishery' is minimal. Many commercial collectors use a frond trimming method they claim is sustainable and allows for multiple collections per year. Unlike cutting at the stipe, which is lethal and can drive populations to extinction, frond trimming preserves the meristem, allowing fronds to regrow. To evaluate the ecological consequences of biomass loss and sustainability of this commercial take method we conducted 2 field experiments. We trimmed fronds at different frequencies and times and then measured: (1) frond regrowth and reproductive output and (2) population recruitment. We explored the potential for geographic variation by replicating the first experiment near the center and southern limit of Postelsia's biogeographic range. Fronds trimmed in April-June were able to regrow and eventually produce viable spores, albeit at somewhat reduced rates. However, spore production was sharply reduced when fronds were trimmed after the onset of sporogenesis (end of July), whether trimmed once or twice. These effects were similar across the geographic range examined but varied in magnitude. Recruitment was $38 \%$ greater in populations not subjected to trimming and population sizes were reduced by 40 to $50 \%$ when trimmed. A precautionary approach to management should: (1) mandate the frond trimming method, (2) limit collection to once a year and (3) close the commercial season before the onset of reproduction.
\end{abstract}

KEY WORDS: Commercial collection · Sea palm · Postelsia palmaeformis · Conservation Management · Kelp

Resale or republication not permitted without written consent of the publisher

\section{INTRODUCTION}

Large, canopy-forming seaweeds including members of the orders Laminariales and Fucales exert a strong influence on intertidal and subtidal community structure (Dayton 1975a, b, Ojeda \& Santelices 1984, Duggins \& Dethier 1985, Blanchette 1994, Kiirikki 1996, Bertness et al. 1999, Burnaford 2004). The abundance of kelps and other seaweeds can vary dramatically among years and locations, and is typically associated with disturbances that cause large removal of biomass or limit productivity including storms (Dayton \& Tegner 1984), herbivory (Graham 2002), light limitation (Ka- vanaugh et al. 2009), bleaching (Harley 2003) and nutrient limitation or oceanographic climate (Dayton et al. 1999, Edwards \& Estes 2006). The rate of recovery from such disturbances depends on propagule (zoospore) supply and mortality of early life history stages. Propagule supply is also influenced by the size and fecundity of source populations and the dispersal ability of propagules (e.g. Graham 2003). Spatial and temporal variation in population sizes of a variety of terrestrial plants (Tilman 1997, Connell \& Green 2000), as well as marine benthic organisms (Underwood \& Fairweather 1989, Caley et al. 1996), is caused by recruitment limitation resulting from constraints on propagule supply. 
Human disturbances, such as commercial or recreational collecting and hunting from wild populations, also result in biomass loss from local populations. Managing these anthropogenic biomass losses from wild populations for sustainable yield typically involves regulations to protect adequate reproductive capacity to support successful recruitment in the future. While the risks of poorly managed human exploitation of marine populations are broadly acknowledged for fish and other marine megafauna, less is known about the consequences for seaweeds, despite a growing market for edible seaweeds (including kelps), increasing evidence that wild populations cannot meet current demand in some places, and the critical role seaweeds play as biogenic habitat and food for many marine animals.

In western North America, commercial collection of edible, wild seaweeds is a growing cottage industry that supplies local, national and global food markets (NB: we preferentially use the word 'collect' in lieu of 'harvest' to distinguish between collecting from wild populations and harvesting a crop that is sown). The edible seaweed 'fishery' on the west coast of the United States is centered in northern California where commercial take has increased dramatically since 2003 (Fig. 1). Commercial regulations vary considerably among states and provinces along the west coast of North America. Two states, Washington and Oregon, completely prohibit commercial collection of edible seaweeds. In California, where the majority of the commercial collecting of edible seaweeds occurs, regulations are minimal and there is no management of the fishery per se. Nonetheless, commercial seaweed collectors typically market their products as 'sustainably harvested' or 'sustainably wildcrafted.' The latter phrase is also used by some commercial collectors of wild mushrooms and medicinal plants, such as Echinacea spp. or American ginseng Panax quinquefolius, and has called into question the sustainability of increasing commercial take from these wild populations (e.g. Schippmann et al. 2002, Case et al. 2007, Price \& Kindscher 2007). As increasing global demand for seaweed has outstripped supply from wild populations in some places, seaweed aquaculture has expanded rapidly (Zemke-White \& Ohno 1999, McHugh 2003, FAO 2004, 2009), providing economic evidence of the mismatch between commercial demand and productive capacity of wild populations (Diana 2009).

A single species of kelp, the sea palm Postelsia palmaeformis (hereafter Postelsia) contributes $45 \%$ to the commercial take of edible seaweed in California (Fig. 1). Postelsia is an annual macroalga with a biphasic life history typical of kelps (Laminariales). A combination of biological characteristics make Postelsia vulnerable to overexploitation: (1) populations are small due to limited availability of suitable habitat and limited dis-

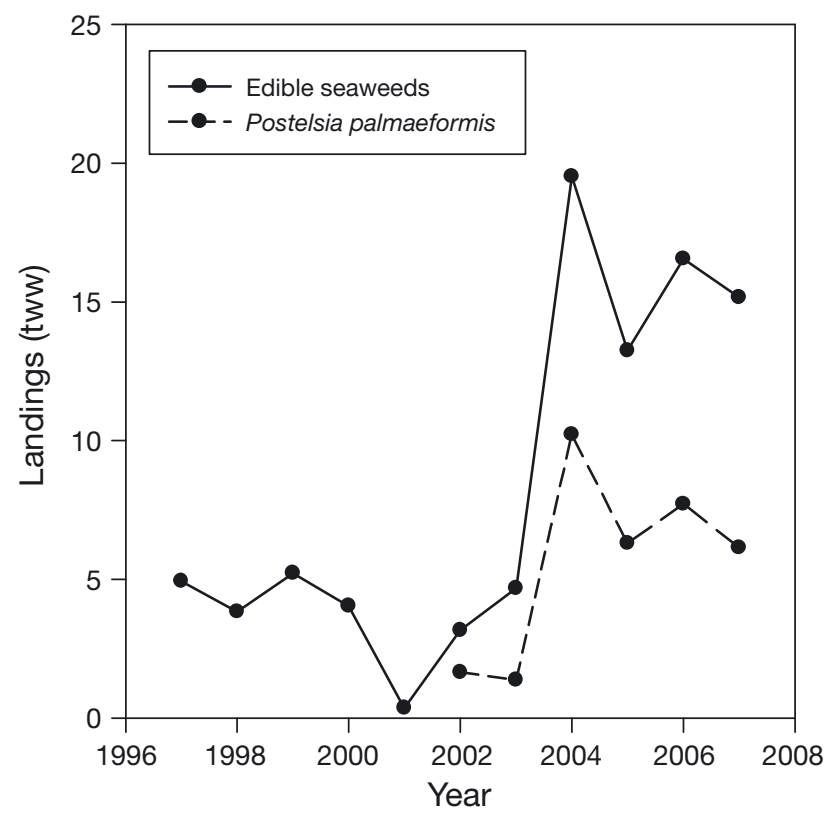

Fig. 1. Commercial take (metric tons wet weight, tww) of edible seaweeds in California, 1997 to 2007. Commercial licensees did not report take by species until 2002. Based on landings records, the collection season runs from April to August, with $53 \%$ of the total take collected in July and $25 \%$ in June. In addition to Postelsia palmaeformis, which constitutes an average of $45 \%$ of the reported commercial take, the following species were also taken (in rank order of take): Laminaria spp., Alaria marginata, Porphyra spp., Nereocystis luetkeana, Fucus spp., Chondracanthus (=Gigartina) spp., Palmaria mollis, Lessoniopsis littoralis, Gelidium spp., Cystoseira sp., Egregia menziesii, Mastocarpus spp., Mazzaella spp., Codium fragile, Ulva spp. and Saccharina (=Hedophyllum) sessile. Source: California Department of Fish \& Game

persal (Dayton 1973, Paine 1979, Coyer et al. 1997, Kusumo et al. 2006); (2) population size is inversely correlated with probability of extinction (Paine 1988); (3) natural population sizes are known to exhibit dramatic interannual variability (Whitmer 2002); (4) spores are produced by sori on the fronds, and these fronds are the targets for commercial collection (Lewallen \& Lewallen 1996); and (5) stipes cannot regrow, thus cutting at the stipe is lethal (Kalvass 1994).

We investigated the effect of biomass loss on frond regrowth, reproductive capacity and recruitment of Postelsia in 2 field experiments. We focused on assessing the influence of the frond trimming method (Lewallen \& Lewallen 1996) used by most commercial collectors (who claim it is sustainable). Since this method results in biomass loss that is not lethal, it provides an opportunity to understand not just the influence of commercial collecting, but also of other biomass-reducing disturbances on population dynamics. We specifically assessed the consequence of biomass loss via frond trimming at different times and frequencies on growth, reproductive output and recruitment. 
Because organisms may experience increased stress and be rarer at the edge of species ranges (Darwin 1859, Hengeveld \& Haeck 1982, Samis \& Eckert 2007), we also explored the potential for variation in response to biomass loss on growth and reproductive output between center and southern edge populations.

\section{MATERIALS AND METHODS}

Study organism. Postelsia is an intertidal kelp found only on the west coast of North America, ranging from Central California, USA $\left(\sim 35^{\circ} \mathrm{N}\right)$, to British Columbia, Canada $\left(\sim 51^{\circ} \mathrm{N}\right)$ (Abbott \& Hollenberg 1976). It has a disturbance-mediated, annual life history with a heteromorphic alternation of generations. Typically, macroscopic sporophytes appear on the shore in late winter or early spring, sporophytes become reproductive during the summer, and senescing plants are largely removed by increasing wave action during the fall and winter (Dayton 1973, Paine 1979, 1988, Blanchette 1996). Sporophytes produce flagellated zoospores in the sorus of each frond that drip down furrows onto nearby surfaces, where they settle, germinate and grow into dioecious, haploid gametophytes (Paine 1979). The gametophytes or, possibly, juvenile sporophytes persist through the winter, often under the mussel bed, becoming apparent on the shore in late winter or early spring, most commonly in patches where mussels or other biota have been removed by winter waves (Dayton 1973, Paine 1979, Blanchette 1996). Postelsia is restricted in its local distribution by environmental stresses associated with tidal height and wave exposure, including desiccation and light limitation (Wing \& Patterson 1993, Nielsen et al. 2006), but it occurs at higher tidal elevations than all other kelps in the northeastern Pacific. Postelsia sporophytes typically grow in aggregations (with individuals as tall as $85 \mathrm{~cm}$ ), forming an extensive canopy that provides shade and protection from desiccation for other intertidal organisms during periods of low tides (Dayton 1975a, Bertness \& Leonard 1997, Burnaford 2004). While Postelsia ultimately depends on disturbance to the mussel bed, the mussel bed initially facilitates survivorship of juvenile stages (Blanchette 1996).

Postelsia has extremely limited dispersal ( $\sim 1$ to $4 \mathrm{~m}$, although drifting of dislodged and reproductively mature plants may contribute to occasional longer distance dispersal events) and is therefore dependent on local reproductive success (Dayton 1973, Coyer et al. 1997). Genetic analyses show relatedness of Postelsia decreases as a function of distance between individuals (Coyer et al. 1997), and there is evidence of inbreeding (Kusumo et al. 2006). The genetic structure of Postelsia populations reflects the localized scale of dispersal and the genetic bottlenecks created as populations go through boom-bust cycles in natural abundance (Whitmer 2002). Furthermore, as expected due to its limited dispersal, small populations are vulnerable to extinction (Paine 1988). These population characteristics suggest that disturbances that reduce survivorship of sporophytes or limit spore production have the potential to increase extinction probabilities and alter local population dynamics and genetic structure.

Experimental design. We conducted 2 field experiments to test the effects of different timings and frequencies of biomass loss through frond trimming (mimicking different potential commercial collection practices) on Postelsia growth, reproductive output and recruitment. Expt 1 was designed to assess the influence of biomass loss on growth and reproductive output in populations near the center and southern limit of Postelsia's biogeographic range. Expt 2 tested the effects of different frequencies of biomass loss on recruitment.

Expt 1 was done in 2006 at 2 sites: (1) Point Cabrillo (PC; $\left.39^{\circ} 20.93^{\prime} \mathrm{N}, 123^{\circ} 49.67^{\prime} \mathrm{W}\right)$, near the center of Postelsia's biogeographic range, and (2) Piedras Blancas Point ( $\mathrm{PB} ; 3^{\circ} 39.92^{\prime} \mathrm{N}, 1^{\circ} 17.20^{\prime} \mathrm{W}$ ) in southern California, the penultimate southern population in its range at the time. At both sites, we set up 4 treatment levels to compare 3 different collecting strategies or disturbance regimes and control: (1) trim early (single biomass removal in late April-early May), (2) trim late (single biomass removal in late July), (3) trim twice (biomass removed in late April-early May and repeated in late July), and (4) control (no biomass removal). To achieve our objectives related to management, we used the commercial frond trimming method advocated by Lewallen \& Lewallen (1996), used by most commercial collectors currently in operation and confirmed to be non-lethal by Kalvass (1994), to effect our biomass removals; all fronds on each plant were cut $\sim 2.5 \mathrm{~cm}$ distal to the meristem. We used a randomized block design with treatment levels applied to all individuals within a $0.125 \mathrm{~m}^{2}$ plot. At the start of the experiment the average density $( \pm \mathrm{SE})$ of individuals per plot was $24.4 \pm 2.4$, and blocks of plots were located within large, contiguous populations. There were 2 replicates of each treatment level within each block. Six blocks were established at $\mathrm{PB}$ and 7 at PC (yielding 48 plots at PB and 56 at PC). The plots were marked at their corners with stainless steel washers stamped with plot numbers. Blocks were haphazardly located in the middle portion of the intertidal elevation zone of each Postelsia population, thus avoiding potentially stressed individuals at the extreme edges of the population's local distribution. All plots were monitored prior to applying any treatments and then 4 to $8 \mathrm{wk}$ after each treatment over a period of $24 \mathrm{~d}$, depending on sea state and timing of low tides. 
The experiment was established and the early trimming treatment implemented at the end of April at $\mathrm{PC}$ and in early May at $\mathrm{PB}_{\text {; }}$ both sites were subsequently monitored in mid to late June and again in late July, just prior to implementing the second trimming treatment. PC was monitored again in early September and early November. PB was monitored once more in early October.

The recruitment experiment was implemented in 2007 and monitored in 2008 . We used 32 populations as our experimental subjects across 4 sites in northern California: Bodega Head $\left(38^{\circ} 18.97^{\prime} \mathrm{N}, 123^{\circ} 4.33^{\prime} \mathrm{W}\right.$; $\mathrm{n}=6)$, Sea Ranch $\left(38^{\circ} 43.80^{\prime} \mathrm{N}, 123^{\circ} 29.32^{\prime} \mathrm{W} ; \mathrm{n}=3\right)$, MacKerricher State Park $\left(39^{\circ} 28.54^{\prime} \mathrm{N}, 123^{\circ} 48.31^{\prime} \mathrm{W}\right.$; $\mathrm{n}=17)$ and Kibesillah Hill $\left(39^{\circ} 36.00^{\prime} \mathrm{N}, 123^{\circ} 47.36^{\prime} \mathrm{W}\right.$; $\mathrm{n}=6$ ). Within each site, we randomly applied 1 of 3 treatment levels to each population during 2007: trim once (single biomass removal in June), trim twice (biomass removed in June and August) and a control (no biomass removal). Because we wanted to assess the effect of biomass removal on recruitment and minimize the potential for additional spore supply from other populations not included in the experiment, we only used populations that were separated from adjacent populations by at least $4 \mathrm{~m}$, corresponding to the maximum documented dispersal distance of spores (Dayton 1973, Coyer et al. 1997). Initial population sizes ranged from 33 to 2729 individuals. Population locations were marked and relocated using GPS coordinates. We monitored recruitment (described below) back into the same populations in June 2008.

Response variables. Frond surface area: In the growth and reproductive output experiment, we assessed frond regrowth after trimming (and growth of controls) by calculating the average individual frond surface area $\left(\mathrm{cm}^{2}\right)$ of plants in each plot on each survey date. Three fronds from each of 3 plants per plot were collected and brought back to the lab to measure frond areas (as well as sorus area, spore production and spore viability used to estimate reproductive output, see below). Fronds were stored in plastic bags in a cooler with ice during transport to the lab, refrigerated in the dark overnight and then processed the following day. To measure frond and sorus areas, fronds were laid flat on a light table (with a ruler for scale) to backlight them and make the sori clearly visible (Nielsen et al. 2006), and then photographed with a digital camera. We analyzed the digital images using ImageJ image analysis software (Rasband 2006) to calculate frond and sorus areas. Frond areas were doubled, as this is more ecologically meaningful because it represents the area available to collect light for photosynthesis and growth, and the 3 frond areas were averaged to yield the average frond surface area (of an individual frond on a single plant).
Biomass yield: We also estimated the different biomass yields commercial collectors would have obtained under each collection strategy represented by the different treatment levels of our experiment from the frond area estimates. For each plot, we converted the average frond surface area to dry weight (DW, g) using a previously determined linear regression model between frond surface area and DW (DW = $0.037 \times 0.5 \times$ frond surface area $-0.092 ; \mathrm{p}<0.0001 ; \mathrm{r}^{2}=$ $0.68 ;$ K. J. Nielsen unpubl. data), then multiplied it by the average frond density per plant and the plant density (no. plants per $0.125 \mathrm{~m}^{2}$ ) to determine the biomass yield per unit area $\left(\mathrm{kg} \mathrm{DW} \mathrm{m}^{-2}\right)$.

Reproductive output: To understand how loss of biomass to commercial collecting might affect reproductive output of Postelsia populations, we quantified reproductive output on a per area basis (no. of viable spores shed per $0.125 \mathrm{~m}^{2}$ per $48 \mathrm{~h}$ ) for each treatment at each site over time by combining estimates of average spore release rate per plant, proportion of viable spores produced and plant density for each plot.

Spore production was estimated by inducing spore release following overnight storage in a dark refrigerator at $9^{\circ} \mathrm{C}$ (Lewis 1995) by placing $1 \mathrm{~cm}^{2}$ of sorus tissue in $0.95 \mathrm{ml}$ of filtered seawater into a $1 \mathrm{dram}(3.7 \mathrm{ml})$ glass vial. Vials were stored in a lit growth chamber at $12^{\circ} \mathrm{C}$ for $48 \mathrm{~h}$, then the sorus tissue was removed and the samples were preserved with $0.05 \mathrm{ml}$ of $37 \%$ formalin (Reed et al. 1997). We estimated the number of spores released per $\mathrm{cm}^{2}$ of surface area by counting spores from 2 replicate $10^{-4} \mathrm{ml}$ aliquots of preserved sample on a hemacytometer slide under a compound microscope at $400 \times$ magnification. For each aliquot, six $1 \mathrm{~mm}^{2}$ fields (volume $=0.1 \mathrm{~mm}^{3}$ ) on the hemacytometer slide were counted and then averaged. The number of spores released per $\mathrm{cm}^{2}$ of sorus (or ml of suspension) over $48 \mathrm{~h}$ was calculated using the average count from the 2 replicates (no, spores $\mathrm{mm}^{-3}$ ) $\times 10^{3}$. To estimate the average number of spores released per plant over a $48 \mathrm{~h}$ period, we multiplied the average number of spores released per $\mathrm{cm}^{2}$ of sorus of each plant by the average sorus area of the fronds, and then by the average frond density for plants in that plot (measured previously in the field).

Spore viability was measured as the percentage of released spores germinating after $48 \mathrm{~h}$. Germination was defined as the presence of a germ tube at least as long as the diameter of the spore (Reed et al. 1996). An $\sim 3 \mathrm{~cm}$ length of frond containing sorus tissue was cut from the center of each frond and placed on a microscope slide in a Petri dish with enough filtered seawater to just cover the frond, then placed in a lit growth chamber at $12^{\circ} \mathrm{C}$ for $24 \mathrm{~h}$. At $24 \mathrm{~h}$, the sorus tissue was removed. Germination of Postelsia spores typically occurs within $24 \mathrm{~h}$ (Lewis 1995). Thus we waited another 
$24 \mathrm{~h}$ before counting germinated and ungerminated spores in 5 random fields of view at $400 \times$ magnification. We estimated the number of viable spores produced per $0.125 \mathrm{~m}^{2}$ plot over $48 \mathrm{~h}$ by multiplying the number of spores produced per plant by the proportion of spores germinating and then by the density of plants in each plot.

Recruitment: In the recruitment experiment, where entire populations were manipulated, we defined posttreatment recruits as sporophytes that were present in June 2008 in the same location as the prior year's population. Although the boundaries of the populations shift somewhat between years, the populations chosen were sufficiently isolated from adjacent populations that they remained distinct. We considered 2 response variables: (1) the difference in population sizes between 2007 and 2008 in June (before and after the experimental treatments, respectively), when population sizes are maximized (Thompson 2007); and (2) the difference in population sizes between August 2007 and June 2008 to represent the relationship between reproductively mature population sizes and the recruits they produced (population sizes typically decline between June and August and most plants do not have well-developed sori or high spore germination rates until August; Nielsen et al. 2006, Thompson 2007).

Statistical analyses. To analyze the results of our experiments, which included both fixed and random effects, we used general linear mixed models (Freund \& Littell 1991) using the mixed procedure in SAS (version 9.1.3). We visually inspected conditional residual plots to assess model fit and transformed response variables to improve distribution of residuals if violation of model assumptions were apparent; transformations, if any, are indicated in the statistical tables.

In Expt 1, site and treatment were considered fixed factors, while block was modeled as a random factor nested within site. We analyzed each sampling date separately even though this experiment was monitored multiple times because different individuals were subsampled each time from each plot, yielding independent observations, and because it was not possible to monitor both sites on all of the later monitoring periods. Additionally, sometimes sampling was limited due to sea state and we could not measure all plots, but before the second and late biomass removals were done we were able to include these plots as additional replicates in the trim early and control treatment levels, respectively (as they were identical at this point in the experiment to those treatment levels), to maximize statistical power. Additionally, a few plots were lost toward the end of the experiment as all plants had been dislodged by waves. Data for all sub-sampled response variables were averaged up to the plot level prior to analysis.
For times when both sites were monitored within 2 wk (or one low tide series) of each other we analyzed the data together, allowing us to assess site $\times$ treatment interactions. The final fall censuses (2 at PC and 1 at PB) occurred at least 1 mo apart, so these data were analyzed separately for each month. Linear (but nonorthogonal) contrast statements were used to assess a priori hypotheses and Tukey's adjustment was used for post hoc comparisons. Contrast statements were coded to examine the following differences: (1) control versus trimmed (all 3 trimming treatment levels combined), to test for an overall effect of biomass removal; (2) early versus late trimming, to test for an effect of the timing of biomass removal; (3) trimming once versus twice, to test for an effect of frequency of biomass removal; and (4) the interaction between frequency and timing of the trimmings, to test whether the effect of removing biomass twice differs from removing biomass just once, regardless of the timing. We used the Bonferroni-corrected $\alpha$-level of 0.0125 to reduce the familywise error rate for all contrast statements.

For Expt 2, treatment was modeled as a fixed factor, site was modeled as a random factor and initial population size (measured in June 2007) was used as a covariate because small population size can increase the risk of extinction (Paine 1988). We tested for inequality of slopes by initially including a treatment $x$ initial population size interaction term in the model, but as the test was not significant $(p>0.57$ for both response variables) we removed the term from the models. We also assessed the random interaction term site $\times$ treatment to see if there was any evidence for site $\times$ treatment interactions, but the covariance parameter estimates for these terms were zero in both models so they were also removed.

\section{RESULTS}

\section{Frond surface area}

Although average frond surface area was indistinguishable between sites or among trimming treatments at the start of the field experiment (treatment: $F_{3,22}=1.73, \mathrm{p}=0.1901$; site: $F_{1,11}=0.25, \mathrm{p}=0.6248$ ), control fronds had greater average surface area at the central population site (PC) than the southern one (PB) on all subsequent monitoring dates (Fig. 2), even when comparing the maximum frond surface area achieved for each site (June at PB and July at PC). Trimmed fronds remained smaller than controls at both sites through the end of the experiment in the fall (October at PB and November at PC; Fig. 2), even though surface areas had sharply declined and converged, presumably due to a combination of senescence, slough- 


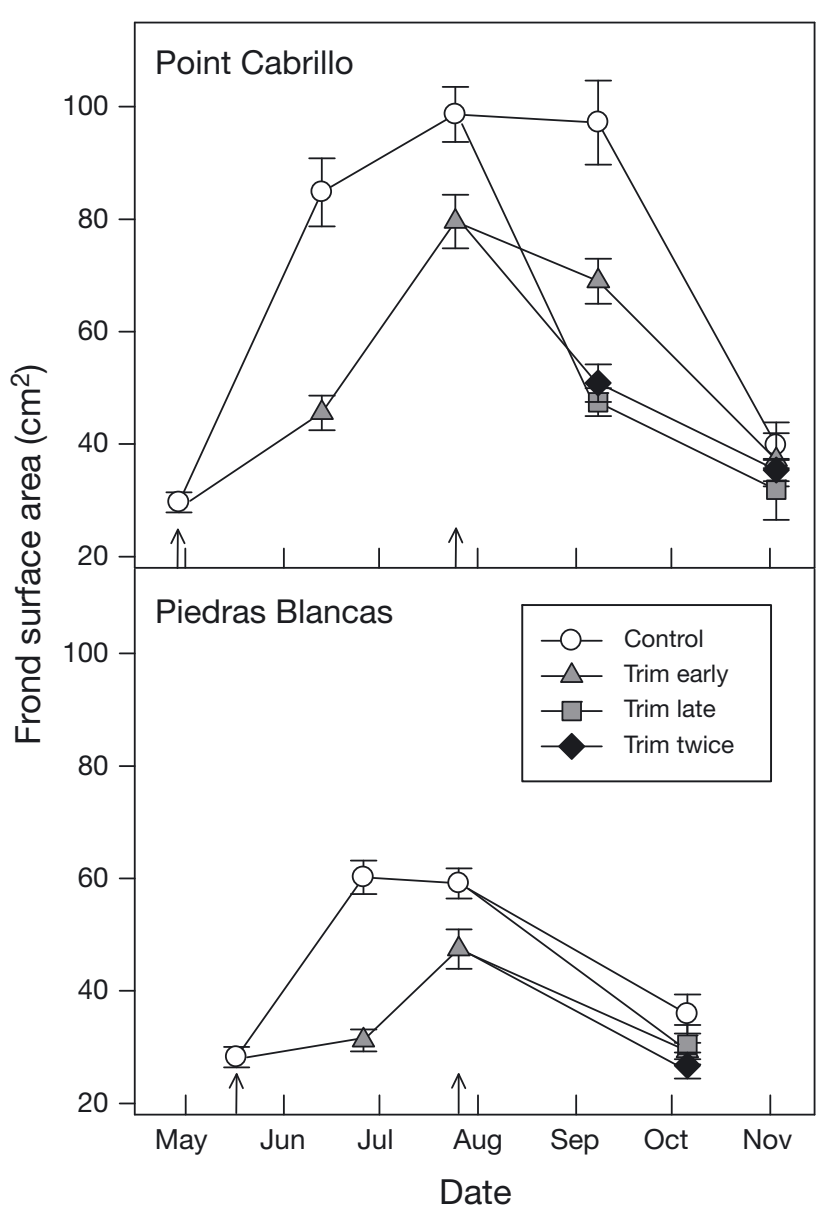

Fig. 2. Postelsia palmaeformis. Frond surface area by treatment over time. Least square means $\pm \mathrm{SE}$ are derived from the statistical model (incorporating random effects) and were back-transformed from the $\log _{10}$ scale. Arrow: date of treatment. Monitoring was done prior to applying treatments. Statistical results see Table 1

ing and erosion (associated with increasing wave action; Fig. 2, Table 1). Interestingly, recovery of fronds trimmed only once appeared to cease by August (Fig. 2). During the summer months, there was no evidence to suggest the response to treatments varied geographically (Table 1).

In September at PC, $6.5 \mathrm{wk}$ after the final trimming had been done for the season, strong differences in frond surface areas among the 4 treatment levels were still evident (Fig. 2, Table 1). Control fronds had greatest surface areas, and surface areas were greater for fronds trimmed once early in the season compared to those trimmed once late in the season and those trimmed twice, which could not be distinguished from those trimmed only once late in the season (Fig. 2, Table 1). Fronds from all non-control treatments appeared to decline in average frond area, especially those trimmed either twice or late in the season (Fig. 2).
By November, there was no discernable difference in surface areas between trimmed and control fronds (Table 1), but not much frond tissue remained on any plant due to predictable seasonal losses as the plants senesced (Fig. 2). By October at PB there was no difference in frond surface areas among the treatments (Table 1); however, as at PC, overall frond area on all plants was largely reduced (Fig. 2).

\section{Biomass yield}

The range of commercial collecting strategies we could evaluate with respect to biomass yield was limited to those explicitly mimicked by our experimental design. If a commercial collector were to collect from a specific location and trimmed the majority of plants in that location during a single month, then average bio-

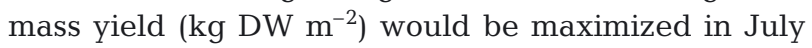
(Table 2), although June yields are not substantially less when considering the confidence intervals. A commercial collector opting to collect twice per year in May and July, again trimming the majority of the plants in both months, would realize yields similar to a single collection in either June or July (Table 2). Even though average frond area was greater at PC (see above), the biomass yield of fronds was similar at both sites (except in May; Table 2) due to differences in frond density (per plant) and plant densities between locations.

\section{Reproductive output}

Although the vast majority of individuals did not have any evidence of sori forming, spores were already being released by a few individuals during our first sampling dates at each site in April and May 2006 (authors' pers. obs.). At the peak of spore production, many billions of viable spores were released over a $48 \mathrm{~h}$ period within each plot (Fig. 3). The peak in spore production for both sites occurred in fall, after the peak in frond area had been achieved (Figs. $2 \& 3$ ). The Postelsia population at PC produced the highest number of viable spores per unit area in September, almost double the peak observed in October at PB (Fig. 3).

In June ( 6 wk post trimming), when production of viable spores was very low in both populations (Fig. 3), there was statistical evidence that the trimmed treatment produced fewer viable spores than the control (Table 3), but this does not appear to be an ecologically meaningful result (Fig. 3). This statistical difference between treatments disappeared by July ( 11 wk post trimming; Table 3), despite the graphical suggestion that it might have persisted or even increased at PB (Fig. 3). 
Table 1. General linear mixed model analysis of Postelsia palmaeformis frond surface area. Data were $\log _{10}$-transformed. Bold text indicates statistically significant results at $\alpha=0.05$ for main effects and at the Bonferroni-corrected level of $\alpha=0.0125$ for all contrasts. See 'Statistical analyses' for details. PC: Point Cabrillo, PB: Piedras Blancas Point. Number of replicates are as follows: 13 control, 22 trim early at PB and 14 control, 28 trim early at PC in June; 25 control, 19 trim early at PB and 24 control, 19 trim early at PC in July; 13 control, 15 trim early, 14 trim late, 13 trim twice at PC in September; 9 control, 10 trim early, 8 trim late, 9 trim twice at PB in October; 10 control, 11 trim early, 9 trim late, 9 trim twice at PC in November. Control vs. Trimmed contrasts controls against trim early, trim late and trim twice treatments combined. Timing contrasts the trim early with the trim late treatments. Frequency contrasts trim early and trim late treatments combined with the trim twice treatment. Frequency $\times$ Timing contrasts trim early with trim twice and trim late with trim twice

\begin{tabular}{|c|c|c|c|c|}
\hline Factor & Numerator df & Denominator df & $F$ & $\mathrm{p}$ \\
\hline \multicolumn{5}{|l|}{ June (after first frond trimming) } \\
\hline Site & 1 & 11 & 25.43 & 0.0004 \\
\hline Treatment (Control vs. Trimmed) & 1 & 11 & 99.5 & $<0.0001$ \\
\hline Site $\times$ Treatment & 1 & 11 & 0 & 0.9577 \\
\hline \multicolumn{5}{|l|}{ July (after first frond trimming) } \\
\hline Site & 1 & 11 & 54.24 & $<0.0001$ \\
\hline Treatment (Control vs. Trimmed) & 1 & 11 & 14.25 & 0.003 \\
\hline Site $\times$ Treatment & 1 & 11 & 0 & 0.9975 \\
\hline \multicolumn{5}{|c|}{ September (PC only; after all treatments applied) } \\
\hline Treatment (all) & 3 & 18 & 26.16 & $<0.0001$ \\
\hline \multicolumn{5}{|l|}{ Contrasts: } \\
\hline Control vs. Trimmed & 1 & 18 & 58.41 & $<0.0001$ \\
\hline Timing & 1 & 18 & 17.85 & 0.0005 \\
\hline Frequency & 1 & 18 & 3.06 & 0.0970 \\
\hline Frequency $\times$ Timing & 2 & 18 & 10.52 & $0.000 \varsigma$ \\
\hline \multicolumn{5}{|c|}{ October (PB only; after all treatments applied) } \\
\hline Treatment & 3 & 12 & 2.96 & 0.0753 \\
\hline \multicolumn{5}{|l|}{ Contrasts: } \\
\hline Control vs. Trimmed & 1 & 12 & 5.38 & 0.0389 \\
\hline Timing & 1 & 12 & 0.64 & 0.4385 \\
\hline Frequency & 1 & 12 & 2.73 & 0.1246 \\
\hline Frequency $\times$ Timing & 2 & 12 & 1.56 & 0.2506 \\
\hline \multicolumn{5}{|c|}{ November (PC only; after all treatments applied) } \\
\hline Treatment (all) & 3 & 15 & 0.37 & 0.7776 \\
\hline \multicolumn{5}{|l|}{ Contrasts: } \\
\hline Control vs. Trimmed & 1 & 15 & 5.38 & 0.0389 \\
\hline Timing & 1 & 15 & 0.52 & 0.4818 \\
\hline Frequency & 1 & 15 & 0 & 0.9760 \\
\hline Frequency $\times$ Timing & 2 & 15 & 0.26 & 0.7743 \\
\hline
\end{tabular}

Table 2. Potential commercial yield (kg dry weight $\mathrm{m}^{-2}$ ) of Postelsia palmaeformis by season of take at Point Cabrillo (PC) and Piedras Blancas Point (PB), California. May, June and July values assume a single collection from the population for the year, whereas the combined May and July value assumes 2 collections from the same population for the year. Data are presented $\pm 95 \%$ CI

\begin{tabular}{|lcc|}
\hline \multirow{2}{*}{ Collection month } & \multicolumn{2}{c|}{ Potential commercial yield } \\
& PC & PB \\
\hline May & $0.25 \pm 0.05$ & $0.69 \pm 0.17$ \\
June & $0.79 \pm 0.15$ & $0.93 \pm 0.19$ \\
July & $1.23 \pm 0.34$ & $1.15 \pm 0.27$ \\
May \& July & $1.18 \pm 0.33$ & $1.64 \pm 0.56$ \\
\hline
\end{tabular}

The most striking consequence of frond trimming was evident in September at PC, $6.5 \mathrm{wk}$ after the second trimming (Fig. 3, Table 3). The number of viable spores produced at PC by the plants trimmed either once late in the summer or twice was dramatically reduced compared to those trimmed once early in the season or not at all, showing very clearly that the timing of trimming had a greater effect on reproductive output than the frequency of trimming (Fig. 3, Table 3). These striking differences disappeared by November $(\sim 14.5 \mathrm{wk}$ after the final trimming), when reproductive output was very low for all 4 treatment levels, suggesting that the plants trimmed late in the season never recovered.

At PB in October ( 10 wk after the final trimming), there was no statistical evidence of any effect of trimming (Table 3), but the untrimmed plants produced slightly more viable spores on average compared to any of the trimmed plants (Fig. 3). Furthermore, in contrast to $\mathrm{PC}$, the trim early plants did not ever appear to recover to control levels of reproductive output, 


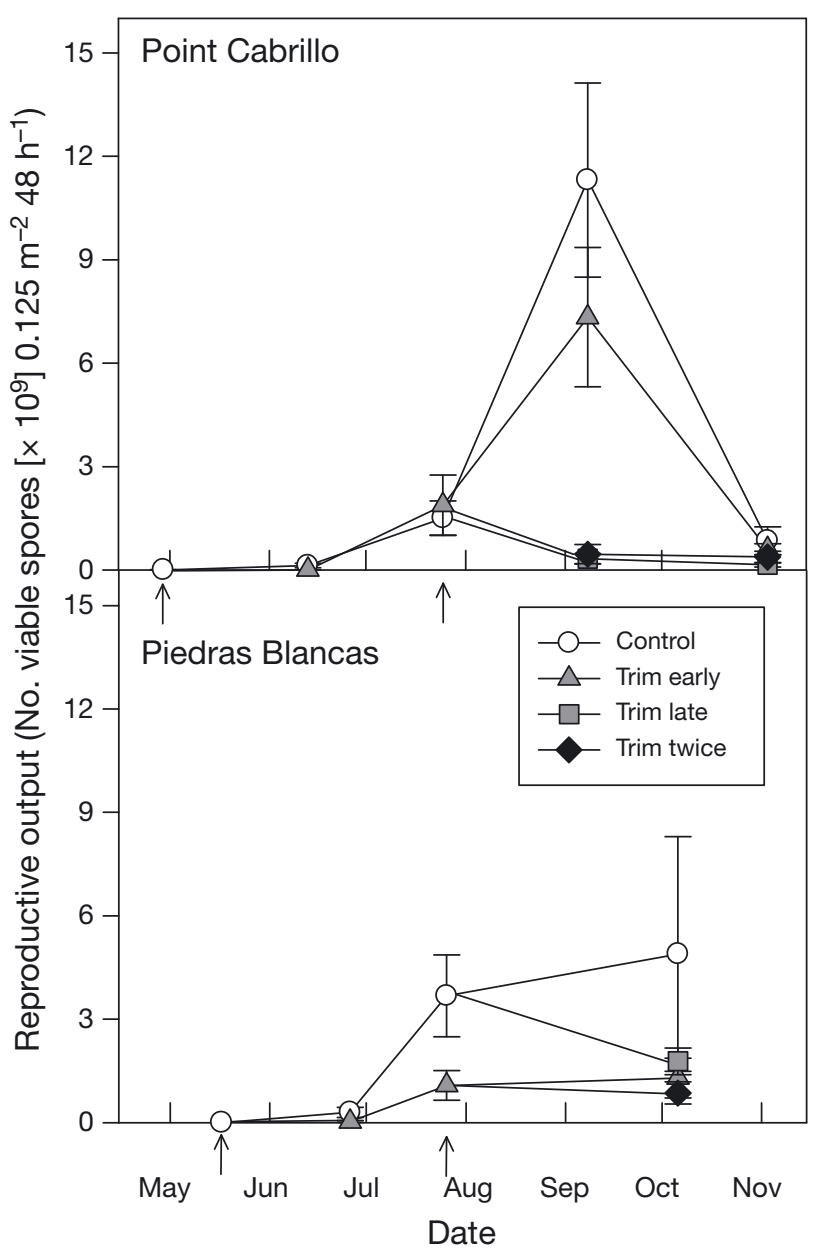

Fig. 3. Postelsia palmaeformis. Reproductive output over time. Statistical results see Table 3. Details as in Fig. 2

although there was large variance in the response of controls (Fig. 3).

\section{Recruitment}

Maximum population sizes subsequent to trimming were smaller for trimmed populations than for those not trimmed at all (Tukey post hoc tests, control vs. trim once: $\mathrm{p}=0.0003$; control vs. trim twice: $\mathrm{p}=0.0048$; trim once vs. trim twice: $\mathrm{p}=0.6130$; Fig. $4 \mathrm{a}$, Table 4 ). The average control population in the present study (initial size $=526$ individuals $)$ did not change in size $(4 \pm$ 43 ind., $p=0.9278$ ) between June 2007 and 2008, while populations that were trimmed declined in size by 40 to $50 \%$ (trim once: $-264 \pm 38$ ind., p $<0.0001$; trim twice: $-211 \pm 40$ ind., $\mathrm{p}<0.0001$ ). There was also a striking negative effect of initial population size on the subsequent year's population sizes (Fig. 4a, Table 4). Although the negative effect of trimming remained evident when considering the change between repro- ductively mature (August 2007) and recruit (June 2008) population sizes (Fig. 4 b, Table 4), there was no evidence for an effect of initial population size over this interval (Fig. 4b, Table 4). Trimmed populations experienced reduced recruitment compared to control populations that experienced no biomass removal (Tukey post hoc tests, control vs. trim once: $p=0.0026$; control vs. trim twice: $\mathrm{p}=0.0063$; trim once vs. trim twice: $\mathrm{p}=$ 0.9858; Fig. 4b, Table 4). Post-treatment recruit populations (June 2008) of average size for the present study (526 individuals) that had not been trimmed the prior year increased by $200 \pm 52$ individuals (or 38\%; $\mathrm{p}=0.0009$ ) over the size of adult populations (August 2007), while populations that were trimmed did not increase at all (trim once: $-25 \pm 46$ ind., $\mathrm{p}=0.5967$; trim twice: $-16 \pm 48$ ind., $p=0.7475$ ).

\section{DISCUSSION}

Our experiments have clearly demonstrated that the removal biomass has a negative effect on Postelsia population dynamics. The results have important management implications for regulating commercial take from Postelsia populations, but also shed light on how non-lethal disturbances that remove substantial biomass or limit productivity of seaweeds, such as herbivory (Graham 2003), changes in oceanographic climate (Dayton et al. 1999, Edwards \& Estes 2006) or light limitation (Kavanaugh et al. 2009), can affect algal population dynamics. The frond trimming method voluntarily adopted by many commercial sea palm collectors in northern California is not lethal and allows fronds to regrow and produce zoospores. The results of the present study, however, demonstrate that there is considerable variation in frond regrowth, reproductive output, recruitment and-more critically - population sizes depending on season and frequency of frond trimming.

In 2006, Postelsia trimmed in late July were much less likely to regrow their fronds and recover the tissue lost to trimming than those trimmed in May, regardless of whether they had been trimmed earlier in the season or not. The dramatic decline in reproductive output seen in these treatments is most likely a consequence of the loss of developing sorus tissue and, more importantly, the lack of regrowth, suggesting an apparent reallocation of energy away from growth and toward reproduction by late summer. Biomass removals from isolated populations made either once (June) or twice (June and August) in 2007 resulted in decreased recruitment in June 2008 compared to populations in which fronds were not trimmed, reducing average population sizes by as much as $50 \%$. These results suggest the timing of sub-lethal disturbances that remove 
Table 3. General linear mixed model analysis of Postelsia palmaeformis reproductive output. Data were $\log _{10}$-transformed. PC: Point Cabrillo; PB: Piedras Blancas Point. Number of replicates: 17 control, 9 trim early at PB and 15 control, 9 trim early at PC in June; 12 control, 11 trim early at PB and 14 control, 14 trim early at PC in July; 13 control, 14 trim early, 14 trim late, 13 trim twice at PC in September; 8 control, 9 trim early, 8 trim late, 9 trim twice at PB in October; 10 control, 10 trim early, 6 trim late, 9 trim twice at PC in November. See Table 1 for additional notes

\begin{tabular}{|c|c|c|c|c|}
\hline Factor & Numerator df & Denominator df & $F$ & $\mathrm{p}$ \\
\hline \multicolumn{5}{|l|}{ June (after first frond trimming) } \\
\hline Site (PC vs. PB) & 1 & 7 & 1.55 & 0.2530 \\
\hline Treatment (Control vs. Trimmed) & 1 & 7 & 6.57 & 0.0374 \\
\hline Site $\times$ Treatment & 1 & 7 & 0.24 & 0.6423 \\
\hline \multicolumn{5}{|l|}{ July (after first frond trimming) } \\
\hline Site (PC vs. PB) & 1 & 6 & 0.23 & 0.6463 \\
\hline Treatment (Control vs. Trimmed) & 1 & 6 & 0.79 & 0.4079 \\
\hline Site $\times$ Treatment & 1 & 6 & 0.65 & 0.4501 \\
\hline \multicolumn{5}{|c|}{ September (PC only; after all treatments applied) } \\
\hline Treatment (all) & 3 & 18 & 18.3 & $<0.0001$ \\
\hline \multicolumn{5}{|l|}{ Contrasts: } \\
\hline Control vs. Trimmed & 1 & 18 & 29.7 & $<0.0001$ \\
\hline Timing & 1 & 18 & 21.3 & 0.0002 \\
\hline Frequency & 1 & 18 & 5.42 & 0.0318 \\
\hline Frequency $\times$ Timing & 2 & 18 & 13.4 & 0.0003 \\
\hline \multicolumn{5}{|c|}{ October (PB only; after all treatments applied) } \\
\hline Treatment (all) & 3 & 10 & 1.44 & 0.2878 \\
\hline \multicolumn{5}{|l|}{ Contrasts: } \\
\hline Control vs. Trimmed & 1 & 10 & 3.96 & 0.0747 \\
\hline Timing & 1 & 10 & 0.19 & 0.6728 \\
\hline Frequency & 1 & 10 & 0.09 & 0.7700 \\
\hline Frequency $\times$ Timing & 2 & 10 & 0.13 & 0.8772 \\
\hline \multicolumn{5}{|c|}{ November (PC only; after all treatments applied) } \\
\hline Treatment (all) & 3 & 11 & 0.89 & 0.4788 \\
\hline \multicolumn{5}{|l|}{ Contrasts: } \\
\hline Control vs. Trimmed & 1 & 11 & 1.02 & 0.3336 \\
\hline Timing & 1 & 11 & 1.77 & 0.2098 \\
\hline Frequency & 1 & 11 & 0 & 0.9505 \\
\hline Frequency $\times$ Timing & 2 & 11 & 0.89 & 0.4390 \\
\hline
\end{tabular}

substantial biomass or limit productivity may be critical in determining the potential effect on population dynamics. Postelsia that suffer a single biomass loss early in the growth cycle may have sufficient time to recover energy stores during regrowth to fuel adequate zoospore production, but biomass losses close to or just after the onset of sporogenesis leave inadequate scope for growth and recovery.

\section{Growth and reproduction}

We observed that fronds trimmed between late April and early May readily regrew, but fronds trimmed later in the summer, after the appearance of mature sorus tissue, did not (Fig. 2). Thus juvenile Postelsia are more able to compensate for biomass losses than reproductively mature individuals. The steep decline in frond area after July (Fig. 2) is most likely the result of 3 factors: the late July trimming treatment (trim late and trim twice), senescence after spore release (all treatments) and loss of tissue from longer fronds due to abrasion against the substratum (trim early and control). These results suggest that once Postelsia individuals start to allocate energy toward reproduction, they allocate very little energy, if any, to growth. We had hypothesized that the regrowth of fronds could follow 1 of 2 paths: regrowth of the immature frond first and then development of sorus, as they do during their natural growth cycle, or regrowth of vegetative and reproductive tissue simultaneously. We observed both phenomena at PC, but at different times of year: the former when fronds were trimmed in the spring before the appearance of sorus, and the latter when fronds were trimmed after the appearance of sorus. However, the rate of regrowth was substantially reduced once sorus tissue began forming, substantially reducing both the viability and yield of spores produced per individual in the later summer trimming treatments (Thompson 2007). In contrast, fronds trimmed in the spring, which recovered vegetative tissue first followed by reproductive tissue, suffered only a slight delay in the onset of 
a

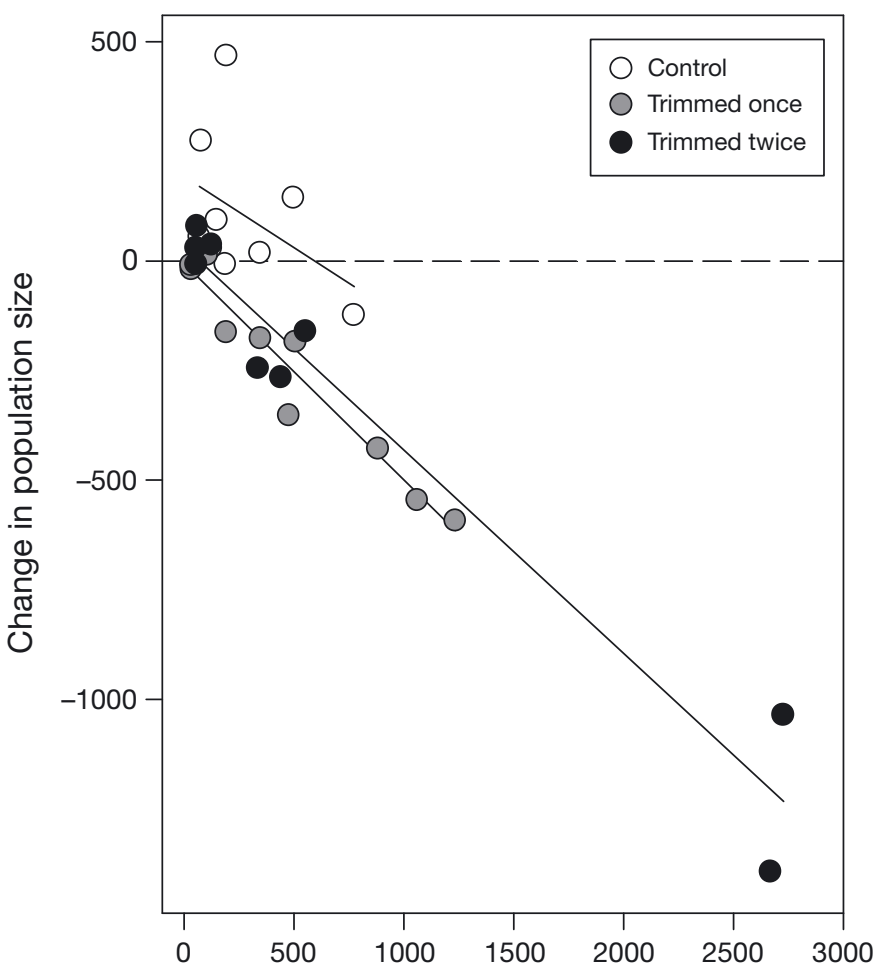

b

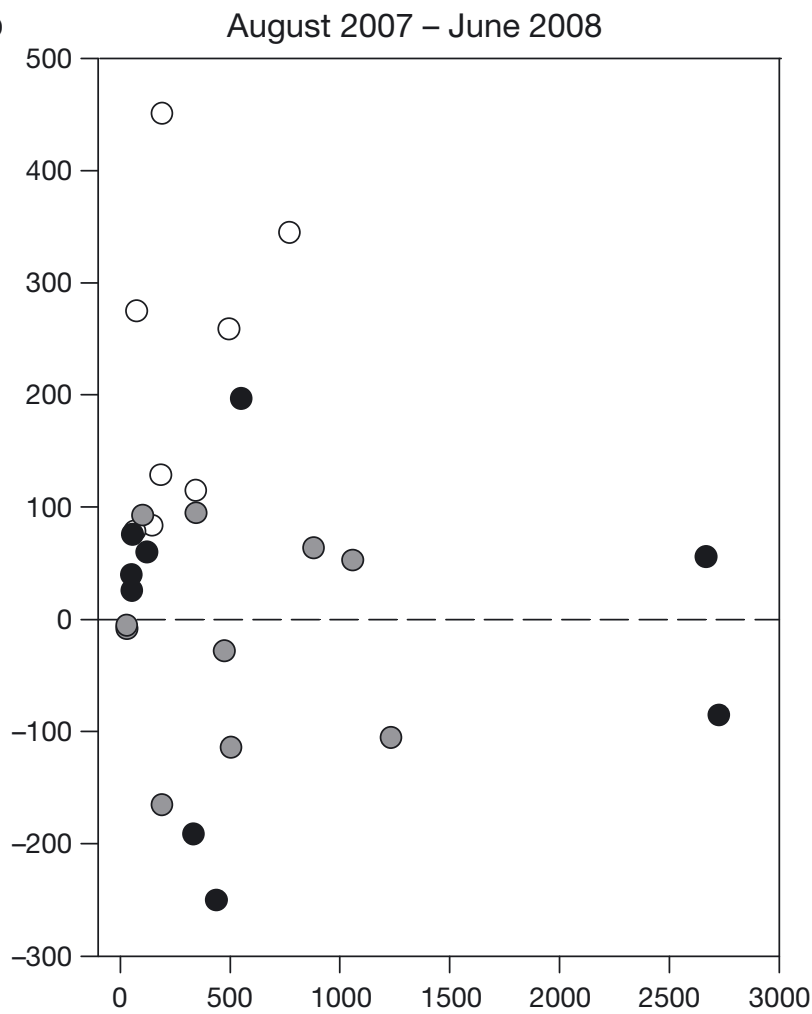

Initial population size (June 2007)

Fig. 4. Postelsia palmaeformis. Change in population size of sporophytes in response to biomass loss treatments in 2007: (a) difference in recruit (pre-reproductive) population sizes between years (i.e. before and after experimental treatments were applied: June 2007 -June 2008), and (b) difference in population sizes between reproductively mature and recruit (pre-reproductive) populations (both are post-treatment: August 2007 - June 2008). Statistical results see Table 4

Table 4. General linear mixed model analysis of change in Postelsia palmaeformis sporophyte population sizes. Note: the interaction terms treatment $\times$ initial population size (fixed) and site $\times$ treatment (random) were evaluated to assess model fit; treatment $\times$ initial population size was not significant in either model $(\mathrm{p}>0.55)$ and site $\times$ treatment yielded estimates of zero in both models, so these effects were not retained. For both models: control $n=8$, trim once $n=10$ and trim twice $n=9$

Change in population sizes of non-reproductive recruits (June 2007-June 2008)

Fixed effects

Numerator df

Denominator df

\begin{tabular}{cr}
$F$ & \multicolumn{1}{c}{$\mathrm{p}$} \\
11.85 & $\mathbf{0 . 0 0 0 4}$ \\
182.21 & $<\mathbf{0 . 0 0 0 1}$
\end{tabular}

Treatment
Initial population size

2

1

21

182.21

0.000

Random effects

Estimate

SE

Z

Site

Residual

0

14064

$-$

4147.13

3.39

$0 . \overline{0003}$

Change in population sizes from adults to non-reproductive recruits (August 2007-June 2008)

Fixed effects Numerator df

Denominator df

\begin{tabular}{|c|c|c|c|c|}
\hline Treatment & 1 & 21 & 8.70 & 0.0018 \\
\hline Initial population size & 1 & 21 & 0.09 & 0.7725 \\
\hline Random effects & Estimate & SE & $Z$ & $\mathrm{p}$ \\
\hline Site & 1708.84 & 3705.15 & 0.46 & 0.3223 \\
\hline Residual & 14830 & 4549.31 & 3.26 & 0.0006 \\
\hline
\end{tabular}


spore production (Thompson 2007). Postelsia reproductive phenology also varies from year to year (authors' pers. obs.), presumably due to interannual variation in nutrient availability, temperature and other climatic conditions, adding an additional layer of complexity to understanding how the timing of biomass losses might affect growth and reproductive output in other years.

Our results are very similar to the response of Nereocystis luetkeana, a species very closely related to Postelsia (Lane et al. 2006), in an experiment done in British Columbia, Canada, to test the effect of commercial collection (Roland 1985). Roland (1985) showed that removing just the frond, while preserving the meristem and basal portion of the fronds, reduced sorus production, canopy cover, percent of fronds with sori and frond growth rate, but did not affect mortality of plants. These effects were more severe when multiple collections were made per year instead of only once (Roland 1985). In South Africa, Levitt et al. (2002) found that trimming the fronds of the perennial kelp Ecklonia maxima rather than the stipe near the holdfast and below the pneumatocyst (as more commonly done) was also not lethal, and taking the secondary fronds (or sporophylls) less frequently and not cutting them as short increased the rate of regrowth. In contrast, the kelp forest perennial Macrocystis pyrifera suffers no known negative effect of commercial collection (Springer et al. 2006) in California, but it is trimmed near the surface of the water leaving behind deeper vegetative fronds and the reproductive sporophylls that are located at the base of the plant (Springer et al. 2006). However, when herbivorous amphipods removed most of the vegetative blade tissue (throughout the water column) of $M$. pyrifera during late summer, its continuously growing sporophylls ceased to release zoospores (even after recovery of sporophyll tissue) while frond regrowth was apparently enhanced, exhibiting a trade-off between growth and reproduction (Graham 2002). These results suggest that responses to biomass loss may only be generalizable among closely related species that share similar life history characteristics and anatomy, such as the annual kelps Postelsia and N. Luetkeana.

The present study did not address the potential indirect effects of removing biogenic habitat, the canopy formed by the fronds and the large holdfasts that are often colonized by small invertebrates (e.g. Smith et al. 1996). Large brown seaweeds also provide food for grazers such as limpets and amphipods while attached, and also after being dislodged, forming wrack on sandy beaches where they increase diversity, providing food and habitat for a variety of small invertebrates that are in turn fed upon by shorebirds (Dugan et al. 2003) or as drift providing food for urchins (e.g. Lester et al. 2007) and other grazers in subtidal ecosystems. However, experimental removal of Postelsia canopy in Oregon did result in changes to the abundance of several understory algal species (Blanchette 1994), strongly suggesting there may also be community level effects of biomass loss.

\section{Geographic variation}

Growth and reproductive output of Postelsia in the control treatments differed between central and southern populations and were also evident in the experimental treatments. The central population (PC) produced a larger number of viable spores in one seasonal peak, while the southern population (PB) sustained more constant production of viable spores over time, albeit at a substantially lower rate (Fig. 3). Populations trimmed late in the summer at PC produced 95\% fewer viable spores than those not trimmed or trimmed only once during the spring, and while the effect of frond trimming on spore production at PB was not as striking, the trend was similar (Table 3, Fig. 3). It is biologically plausible that variation in environmental conditions between these 2 regions are sufficiently different, and the populations are sufficiently isolated, that local adaptation may be responsible for the variation in phenology and response to treatments we observed. The decline in reproductive output at PB could also be attributed to stressful physical conditions experienced by southern range-edge populations. Observations of the most southern population of Postelsia located near Diablo Canyon that went extinct during the $1998 \mathrm{El}$ Niño event and never recovered (S. Krenn pers. comm., authors' pers. obs.) support this line of reasoning. Further study of differences in physical conditions as well as the population genetics within and among sites across Postelsia's geographic range is needed to better understand the factors responsible for this phenological variation.

\section{Recruitment}

In 2008, Postelsia recruitment and population sizes were negatively affected by biomass losses (frond trimming) during the previous year, whether done once (June) or twice (June and August; Fig. 4). Although it was not surprising that control populations had greater recruitment than populations trimmed twice and were able to maintain similar population sizes, it was surprising that populations trimmed only once exhibited the same response as those trimmed twice. Based on the results from the growth and reproductive output experiment in 2006 in the same region, we would have 
expected only the trim twice treatment to have suffered spore limitation or reduced population sizes (upper panel Fig. 3, Table 3). Differences in environmental conditions between years may be responsible. However, because we delayed the early trimming by $1 \mathrm{mo}$ in 2007 compared to 2006 it is also possible we waited too long to minimize the effect of the biomass loss on scope for recovery, even though plants were not yet producing sori and readily regrew (authors' pers. obs.), as in 2006. Further work is needed to distinguish among these possibilities and assess how late in the growth cycle biomass losses can be sustained (or compensated for) without consequences to population dynamics.

Maximum population size declined for populations that were trimmed, presumably due to spore limitation (Fig. 4, Table 4), but population size also had a negative effect, when considering changes over the entire year (cf. Figs. 4a, b, Table 4). Although spore supply to populations might also be limited by small population size per se (Paine 1988) or augmented by supply from nearby populations (Dayton 1973, Paine 1979, Coyer et al. 1997, Kusumo et al. 2006), we found no evidence for a positive effect of initial population size (Fig. 4b, Table 4) or any indication that distance to the closest population (linear regression, $\mathrm{p}=0.9688, \mathrm{r}^{2}=0.0001$ ) influenced recruitment from reproductively mature populations (August 2007). There was, however, strong evidence of recruitment limitation (Fig. 4b, Table 4), presumably due to reduced spore supply associated with the trimming treatments (although strictly speaking we cannot rule out the possibility of increased mortality of early life history stages as a mechanism on the basis of these results alone). Our results provide strong support for the hypothesis that spore limitation mediates recruitment and, ultimately, population size, independent of initial population size.

Large population size apparently has a negative effect on survivorship between June and August; as plants reach reproductive maturity, individual size is maximized and larger individuals start being removed by waves (Nielsen et al. 2006, Thompson 2007). We hypothesize that the mechanism responsible for this effect is that larger populations are denser, promoting intraspecific competition for space and light, resulting in holdfast overgrowth and taller plants that are more susceptible to dislodgement.

Evidence of the negative effect of commercial take on population dynamics can be found in studies of other large brown, habitat-forming seaweeds such as rockweed Ascophyllum nodosum in the North Atlantic and cochayuyo or bull kelp Durvillaea antarctica in the South Pacific (Keser et al. 1981, Lazo \& Chapman 1996, Castilla et al. 2007). In Chile, D. antarctica has been exploited for human consumption initially by the Mapuches and now by modern intertidal subsistence food-gatherers and artisanal fishers (similar to the history of the Postelsia fishery in northern California; Castilla et al. 2007). Creation of a no-take marine reserve in an area that had previously been subject to commercial collection resulted in dramatic increases ( $\sim 3$ orders of magnitude) in plant density and biomass inside the reserve compared to outside, but only after 7 yr of protection (Castilla et al. 2007). Increases in abundance of populations adjacent to but outside of the reserve started to occur after about $9 \mathrm{yr}$, most likely as a result of re-seeding by spores spilling over from inside the reserve.

Rockweed has been collected commercially in Europe for several centuries, more recently in Canada, and most recently has begun expanding into Maine where it has generated significant controversy among regional stakeholders (Seip 1980, Ugarte \& Sharp 2001, Tomsho 2010). It is primarily used for extraction of alginates (for industrial processes) and as agricultural fertilizer rather than for human consumption. Improper collecting techniques eliminated some populations in France and recovery was estimated to take up to $15 \mathrm{yr}$ (Keser et al. 1981). Removal of rockweed can also have strong negative effects on the abundance and diversity of intertidal animals (Boaden \& Dring 1980). In an experiment in Maine comparing regrowth of rockweed under different collection methods (cutting at the holdfast, 15 or $25 \mathrm{~cm}$ from the holdfast), Keser et al. (1981) found that regrowth was least in areas where plants were cut at the holdfast, especially when grazers (Littorina littorea) were present. In areas where plants were cut at 15 or $25 \mathrm{~cm}$, regrowth depended on the age structure of the population. Younger plants regrew more readily than older plants, but nonetheless, biomass yields declined over 3 yr of repeated collecting, suggesting a loss of regenerative capacity in response to repeated annual take, consistent with a modeling study exploring different collecting strategies (Seip 1980).

Decline of wild seaweed populations associated with take by humans is not a modern phenomenon. In Hokkaido, Japan, a kombu Laminaria angustata fishery has been in existence since at least the eighteenth century (Iida 1998). High market demand and the subsequent decline of wild populations resulted in spatial expansion of the kombu fishery and, as early as the late $1800 \mathrm{~s}$, seaweed collectors observed that kombu was being replaced by other seaweed species (Iida 1998). Currently, the kombu fishery in Hokkaido is regulated by a combination of seasonal limits, method of take and participation entitlements (Iida 1998) to prevent overexploitation and population declines. 


\section{Management and conservation}

In Asian cultures where human consumption of seaweed is high, large-scale aquaculture rather than extraction from wild populations supplies commercial demand (e.g. kombu, nori, wakami, etc.; McHugh 2003, FAO 2004). Aquaculture production of seaweed increased by $7 \pm 2 \%$ (95\% CI) per year between 1998

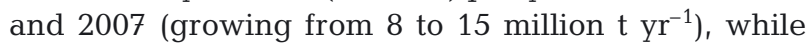
capture from wild seaweed populations remained sta-

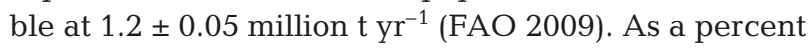
of market value, over $80 \%$ of commercial seaweed is destined for human consumption (McHugh 2003). Although Asia currently produces and consumes the vast majority of commercially available seaweed, demand outside Asia is also increasing (FAO 2004, 2009).

The growing market for seaweeds internationally as well as within the US, combined with outdated or limited regulatory oversight, is cause for attention. Concern about the sustainability of commercial collection of Postelsia surfaced in the 1980s when some populations were apparently being clear-cut at the stipe and subsequently declined or disappeared (P. Kalvass pers. comm.). This method (allowable under current regulations) will cause local populations to go extinct if done prior to spore release and if there is no nearby (within $\sim 5 \mathrm{~m}$ ) source of spores (H. Knoll \& K. J. Nielsen unpubl. data). Most reputable commercial Postelsia collectors don't use this method, but instead use the non-lethal frond trimming method (Lewallen \& Lewallen 1996). They also attempt to maintain exclusive territories through informal agreements, but newcomers and poachers are not necessarily aware or respectful of these territories (authors' pers. obs.). Based on the evidence from the present and other studies of commercially exploited seaweeds, it would be prudent to proactively manage this growing fishery to avoid negative consequences.

We recommend regulations for commercial collection of Postelsia mandate the use of the frond trimming method, limit collection to once a year per population and set a collecting season that closes before the onset of reproduction. Site-specific licenses and a single collection per population early in the season will limit the total biomass available to collectors at a given location (Table 2), but it also provides the most desirable product for collectors: the tender, young fronds (authors' pers. obs.). These management recommendations would be relatively easy to implement and enforce and are similar to the informal agreements and practices of commercial collectors attempting to build sustainable business practices. The main differences between commercial collectors' informal agreements and the management recommendations we make lie in how often collection occurs at a site and when commercial collecting is done (landings records and informal interviews indicate July is the peak in commercial collection). An alternative management strategy might be to limit the percentage of the population that may be harvested at any site, but this may be more challenging to enforce and additional experiments would need to be done to determine the appropriate percentage. Depending on the year and region, it might also be possible to recommend collecting as late in the season as June, when the available biomass is greater, but further work would need to be done to understand the environmental correlates of interannual variation in phenology.

Due to the effects on fitness and reduction in population sizes we observed under some regimes of biomass loss, minimizing changes to reproductive output may be critical in reducing the potential for altering genetic structure and phenology (e.g, Schippmann et al. 2002, Allendorf \& Hard 2009), an important but often underappreciated facet in developing truly sustainable management of commercial take from wild populations.

\section{CONCLUSIONS}

These experiments have shown that Postelsia population dynamics are sensitive to the timing of biomassremoving disturbances, including some commercial collecting practices. Reproductive output, recruitment and population size are negatively affected by biomass removals made close to the onset of sporogenesis. The range of commercial collection practices allowable under current regulations in California will not provide adequate protection to develop a sustainable fishery as market demand continues to grow. History has shown us that the collapse of commercially targeted species often occurs when management is designed to optimize take (Dayton 1998), rather than optimizing longterm sustainability. The Postelsia fishery has the potential to become a good model for how to balance conservation and commercial goals using evidencebased management if appropriate regulatory precautions, such as the ones we describe above, are incorporated into a management plan.

Acknowledgements. We thank B. Brockbank for his enthusiasm in the field and lab, as well as many student volunteers from UCSB and SSU for field assistance. KJN especially thanks her son A. Brady for pinch-hitting in the field when she broke her wrist. E. Sanford, J. H. Cushman and 4 anonymous reviewers provided insightful comments, and C. Christian helped instigate this project. We gratefully acknowledge J. Kimbrell (Point Cabrillo Lighthouse Keepers Association), California State Parks, J. Bogacki (Bureau of Land Manage- 
ment) J. Sones (Bodega Marine Laboratory) and the Monterey Bay National Marine Sanctuary (National Marine Sanctuary Permit MBNMS-2005-034) for facilitating site access, and L. Bennett-Rogers and B. Owens (California Department of Fish and Game) for facilitating access to the edible seaweed landings data. This publication was supported in part by the National Sea Grant College Program of the US Department of Commerce's National Oceanic and Atmospheric Administration under NOAA Grant no. NA04OAR4170038, project no. R/CZ-200 to K.J.N. and C.A.B., through the California Sea Grant College Program; and in part by the California State Resources Agency. The views expressed herein do not necessarily reflect the views of any of those organizations. Additional funding was provided by an SSU Research, Scholarship and Creative Activity Program mini-grant to K.J.N.; the Joe and Judy Brumbaugh Scholarship to S.A.T.; and the Partnership for Interdisciplinary Studies of Coastal Oceans to C.A.B.

\section{LITERATURE CITED}

Abbott IA, Hollenberg GJ (1976) Marine algae of California. Stanford University Press, Stanford, CA

Allendorf FW, Hard JJ (2009) Human-induced evolution caused by unnatural selection through harvest of wild animals. Proc Natl Acad Sci USA 106:9987-9994

Bertness MD, Leonard GH (1997) The role of positive interactions in communities: lessons from intertidal habitats. Ecology 78:1976-1989

Bertness MD, Leonard GH, Levine JM, Schmidt PR, Ingraham AO (1999) Testing the relative contribution of positive and negative interactions in rocky intertidal communities. Ecology 80:2711-2726

Blanchette CA (1994) The effects of biomechanical and ecological factors on population and community structure of wave-exposed, intertidal macroalgae. $\mathrm{PhD}$ thesis, Oregon State University, Corvallis, OR

Blanchette CA (1996) Seasonal patterns of disturbance influence recruitment of the sea palm, Postelsia palmaeformis. J Exp Mar Biol Ecol 197:1-14

> Boaden PJS, Dring MT (1980) A quantitative evaluation of the effects of Ascophyllum harvesting on the littoral ecosystem. Helgol Mar Res 33:700-710

Burnaford JL (2004) Habitat modification and refuge from sublethal stress drive a marine plant-herbivore association. Ecology 85:2837-2849

Caley MJ, Carr MH, Hixon MA, Hughes TP, Jones GP, Menge BA (1996) Recruitment and the local dynamics of open marine populations. Annu Rev Ecol Syst 27:477-500

Case MA, Flinn KM, Jancaitis J, Alley A, Paxton A (2007) Declining abundance of American ginseng (Panax quinquefolius L.) documented by herbarium specimens. Biol Conserv 134:22-30

Castilla JC, Campo MA, Bustamante RH (2007) Recovery of Durvillaea antarctica (Durvilleales) inside and outside Las Cruces Marine Reserve, Chile. Ecol Appl 17:1511-1522

> Connell JS, Green PT (2000) Seedling dynamics over thirtytwo years in a tropical rain forest tree. Ecology 81:568-584

Coyer JA, Olsen JL, Stam WT (1997) Genetic variability and spatial separation in the sea palm kelp Postelsia palmaeformis (Phaeophyceae) as assessed with M13 fingerprints and RAPDS. J Phycol 33:561-568

Darwin C (1859) On the origin of species by means of natural selection. Bantam, New York

> Dayton PK (1973) Dispersion, dispersal, and persistence of the annual intertidal alga, Postelsia palmaeformis Ruprecht. Ecology 54:433-438
Dayton PK (1975a) Experimental evaluation of ecological dominance in a rocky intertidal algal community. Ecol Monogr 45:137-159

Dayton PK (1975b) Experimental studies of algal canopy interactions in a sea otter-dominated kelp community at Amchitka Island, Alaska. Fish Bull 73:230-237

> Dayton PK (1998) Reversal of the burden of proof in fisheries management. Science 279:821-822

> Dayton PK, Tegner MJ (1984) Catastrophic storms, El Niño, and patch stability in a southern California kelp community. Science 224:283-285

> Dayton PK, Tegner MJ, Edwards PB, Riser KL (1999) Temporal and spatial scales of kelp demography: the role of oceanographic climate. Ecol Monogr 69:219-250

- Diana JS (2009) Aquaculture production and biodiversity conservation. Bioscience 59:27-38

Dugan JE, Hubbard DM, McCrary MD, Pierson MO (2003) The response of macrofauna communities and shorebirds to macrophyte wrack subsidies on exposed sandy beaches of southern California. Estuar Coast Shelf Sci 58:25-40

> Duggins DO, Dethier MN (1985) Experimental studies on herbivory and algal competition in a low intertidal habitat. Oecologia 67:183-191

Edwards MS, Estes JA (2006) Catastrophe, recovery and range limitation in NE Pacific kelp forests: a large-scale perspective. Mar Ecol Prog Ser 320:79-87

FAO (2004) The state of world fisheries and aquaculture 2004. FAO, Rome, available at www.fao.org/docrep/007/ y5600e/y5600e00.htm

FAO (2009) FAO yearbook: fisheries and aquaculture statistics 2007. FAO, Rome, available at ftp://ftp.fao.org/ docrep/fao/012/i1013t/i1013t.pdf

Freund RJ, Littell R (1991) SAS system for linear models, 3rd edn. SAS Institute, Cary, NC

Graham MH (2002) Prolonged reproductive consequences of short-term biomass loss in seaweeds. Mar Biol 140: 901-911

Graham MH (2003) Coupling propagule output to supply at the edge and interior of a giant kelp forest. Ecology 84: $1250-1264$

- Harley CDG (2003) Abiotic stress and herbivory interact to set range limits across a two-dimensional stress gradient. Ecology 84:1477-1488

Hengeveld R, Haeck J (1982) The distribution of abundance. 1. Measurements. J Biogeogr 9:303-316

> Iida T (1998) Competition and communal regulations in the kombu kelp (Laminaria angustata) harvest. Hum Ecol 26: 405-423

Kalvass PE (1994) The effect of different harvest methods on sea palm (Postelsia palmaeformis) sporophyll growth. Calif Fish Game 80:57-67

Kavanaugh MT, Nielsen KJ, Menge BA, Chan FT, Letelier RM, Goodrich LM (2009) Experimental assessment of the effects of shade on an intertidal kelp: Do phytoplankton blooms inhibit growth of open coast macroalgae? Limnol Oceanogr 54:276-288

Keser M, Vadas RL, Larson BR (1981) Regrowth of Ascophyllum nodosum and Fucus vesiculosus under various harvesting regimes in Maine, U.S.A. Bot Mar 24:29-38

Kiirikki M (1996) Experimental evidence that Fucus vesiculosus (Phaeophyta) controls filamentous algae by means of the whiplash effect. Eur J Phycol 31:61-66

Kusumo HT, Pfister CA, Wootton JT (2006) Small-scale genetic structure in the sea palm Postelsia palmaeformis Ruprecht (Phaeophyceae). Mar Biol 149:731-742

> Lane CE, Mayes C, Druehl LD, Saunders GW (2006) A multigene molecular investigation of the kelp (Laminariales, 
Phaeophyceae) supports substantial taxonomic re-organization. J Phycol 42:493-512

Lazo L, Chapman ARO (1996) Effects of harvesting on Ascophyllum nodosom (L.) Le Jol. (Fucales, Phaeophyta): a demographic approach. J Appl Phycol 8:87-103

Lester SE, Gaines SD, Kinlan BP (2007) Reproduction on the edge: large-scale patterns of individual performance in a marine invertebrate. Ecology 88:2229-2239

Levitt GJ, Anderson RJ, Boothroyd CJT, Kemp FA (2002) The effects of kelp harvesting on its regrowth and the understorey benthic community at Danger Point, South Africa, and a new method of harvesting kelp fronds. S Afr J Mar Sci 24:71-85

Lewallen E, Lewallen J (1996) Sea vegetable gourmet cookbook and wildcrafter's guide. Mendocino Sea Vegetable Company, Philo, CA

Lewis RJ (1995) Gametogenesis and chromosome number in Postelsia palmaeformis (Laminariales, Phaeophyceae). Phycol Res 43:61-64

McHugh DJ (2003) A guide to the seaweed industry. FAO Fish Tech Pap 441. FAO, Rome

Nielsen KJ, Blanchette CA, Menge BA, Lubchenco J (2006) Physiological snapshots reflect ecological performance of the sea palm, Postelsia palmaeformis (Phaeophycaea) across intertidal elevation and exposure gradients. J Phycol 42:548-559

Ojeda FP, Santelices B (1984) Ecological dominance of Lessonia nigrescens (Phaeophyta) in central Chile. Mar Ecol Prog Ser 19:83-91

Paine RT (1979) Disaster, catastrophe, and local persistence of the Sea Palm Postelsia palmaeformis. Science 205: 685-687

Paine RT (1988) Habitat suitability and local population persistence of the Sea Palm Postelsia palmaeformis. Ecology 69:1787-1794

Price DM, Kindscher K (2007) One hundred years of Echinacea angustifolia harvest in the smoky hills of Kansas, USA. Econ Bot 61:86-95

Rasband WS (2006) ImageJ. US National Institutes of Health, Bethseda, MD

Reed DC, Ebeling AW, Anderson TW, Anghera M (1996) Differential reproductive responses to fluctuating resources in two seaweeds with different reproductive strategies. Ecology 77:300-316

Reed DC, Anderson TW, Ebeling AW, Anghera M (1997) The role of reproductive synchrony in the colonization potential of kelp. Ecology 78:2443-2457

Roland WG (1985) Effects of lamina harvest on the bull kelp, Nereocystis luetkeana. Can J Bot 63:333-336

Editorial responsibility: Lisandro Benedetti-Cecchi, Pisa, Italy
Samis KE, Eckert CRG (2007) Testing the abundant center model using range-wide demographic surveys of two coastal dune plants. Ecology 88:1747-1758

Schippmann U, Leaman DJ, Cunningham AB (2002) Impact of cultivation and gathering of medicinal plants on biodiversity: global trends and issues. In: Biodiversity and the ecosystem approach in agriculture, forestry and fisheries. FAO, Rome, available at www.fao.org/docrep/005/ Y4586E/Y4586E00.htm

Seip KL (1980) A computational model for growth and harvesting of the marine alga Ascophyllum nodosum. Ecol Model 8:189-199

> Smith SDA, Simpson RD, Cairns SC (1996) The macrofaunal community of Ecklonia radiata holdfasts: description of the faunal assemblage and variation associated with differences in holdfast volume. Aust J Ecol 21:81-95

Springer Y, Hays C, Carr M, Mackey M, Bloeser J (2006) Ecology and management of the bull kelp, Nereocystis luetkeana: a synthesis with recommendations for future research. Lenfest Ocean Program at The Pew Charitable Trusts, Washington, DC, available at www.lenfestocean. org/publications/springer_underlying_report.pdf

Thompson SA (2007) Balancing conservation with commercial use: an experiment to guide sustainable exploitation of an ecologically vulnerable kelp. MSc thesis, Sonoma State University, Rohnert Park, CA

> Tilman D (1997) Community invasibility, recruitment limitation, and grassland biodiversity. Ecology 78:81-92

Tomsho R (2010) Scraping bottom, some in Maine look to seaweed for salvation: fight over habitat damage puts at risk source of income for hard-hit coastal towns. The Wall Street Journal, New York, NY, available at http://online. wsj.com/article/SB126256780507514279.html

Ugarte RA, Sharp G (2001) A new approach to seaweed management in eastern Canada: the case of Ascophyllum nodosum. Cah Biol Mar 42:63-70

Underwood AJ, Fairweather PG (1989) Supply-side ecology and benthic marine assemblages. Trends Ecol Evol 4: 16-19

Whitmer AC (2002) Population dynamics and genetics of the intertidal kelp Postelsia palmaeformis. PhD dissertation, University of Washington, Seattle, WA

> Wing SR, Patterson MR (1993) Effects of wave-induced light flecks in the intertidal zone on photosynthesis in the macroalgae Postelsia palmaeformis and Hedophyllum sessile (Phaeophyceae). Mar Biol 116:519-525

> Zemke-White WL, Ohno M (1999) World seaweed utilization: an end-of-the century summary. J Appl Phycol 11: 369-376

Submitted: November 5, 2009; Accepted: June 11, 2010

Proofs received from author(s): August 18, 2010 